\title{
15年の経過をとった気管支腺原発の 肺癌の一剖検例
}

\author{
An autopsy case of bronchial gland adenocarcinoma \\ survived for fifteen years.
}

稲田啓一 ${ }^{*} \cdot$ 藤岡大司郎* $*$ 中田耕太 $*^{*} \cdot$ 曾和健次 ${ }^{*} \cdot$ 竹村 正 $^{* *} \cdot$ 北村 旦 $^{* *}$

\begin{abstract}
抄録：初発時33才男性, 右肺門部腫瘤のため右肺上葉切除術施行. 組織学的に唾液腺腫瘍型の 粘液産生性腺房腺癌で, 所属リンパ節の転移部には乳頭状, 霊胞状腺癌の像が見られた。 術後11年目に再発，その 3 年後に胸水貯留し，全身転移で死亡した。その全経過と特異 な組織像から気管支腺原発の腺癌と考えられる非常に稀な興味ある症例であるので, そ の発生, 組織学的特徵につき考察を加える.
\end{abstract}

\section{はじめに}

気管支carcinoidや肺の oat cell carcinomaに ついての研究が進むにつれて, 最近気管支腺よ り発生する腫痬への関心が高まり，少数ではあ るがそのような腫瘍が報告されるようになって きたが,その多くは従来の adenoid cystic carcinomaやmucoepidermoid carcinoma などであり， 本来の意味の気管支腺原発の腫瘍, 特に腺癌と 思われる報告はあまり見られない。気管支腺由 来の決定は気管支粘液腺の唾液腺との類似から， その腫瘍の一部に唾液腺腫瘍の特徵を見出す以 外は非常に困難と言ってょい. 我々は最近, 唾 液腺腫瘍型の組織像を呈し，気管支腺原発と考 えられる腺癌の一例を経験し，剖検する機会を 得たので，その特異な長期の経過と組織像につ いて報告し，あわせて気管支腺原発の腫瘍につ いて文献的考察を加える。

*

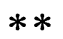

$* * *$
大阪聥信病院第二内科

同第二臨床検査科

大阪大学医学部第一病理

\section{症 例}

33才男性 (死亡時 48 才), 電々公社社員. 昭和 36 年6月の定期健康診断で右肺門部に円形(直径 約 $3 \mathrm{~cm}$ )の異常㓌影を発見され，当院に紹介さ れてきた。(Fig.1)特記すべき既往歴なく，タバ コは 1 日10本，肺腫瘍，肺結核の両面から精查 するも確診できず，一応抗結核三者療法を 6 力 月間施行したが，陰影は漸次増大，昭和 36 年 12 月の右頸部リンパ節試験切除, 及び頻回の喀痰 細胞診でも悪性所見は認めなかったが，臨床経 過より肺腫瘍として 37 年 1 月，右肺上葉を切除 した。手術肺の肉眼的所見では, 腫瘍は直径 3 $\mathrm{cm}$ 大, 灰白色で割面に粘液が多量に見られた。 腫場は上葉の肺葉気管支壁にあり，一部気管支 内腔に突出し，大部分は気管支周囲に発育して いた.(Fig.2)所属リンパ節にもすでに 1 力所転 移を認めた。手術時の腫瘍の組織像はFig.3に示 すように気管支粘液腺あるいは唾液腺腫瘍を思 わせるような, 粘液を多量に含んだ細胞が腺房 状に配列し，時々これが集合して小葉形成を思 わせるような腺房腺癌の部分とFig. 4 のような 間質結合織の増生を伴い，不規則な管腔を形成 
Fig.1 発見時, 右肺門部に円形の㓌影を認める.
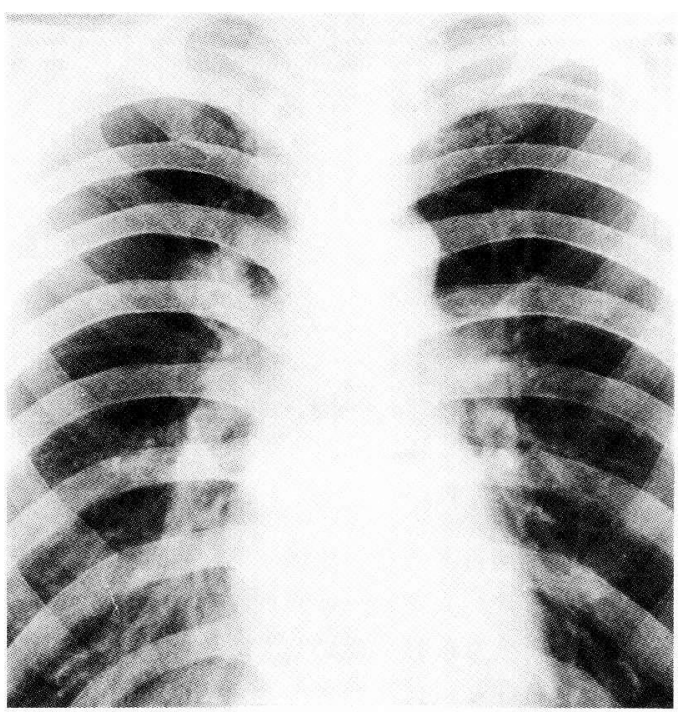

Fig. 2 右上葉の切除肺, 腫瘍は上葉気管支壁に見 られる。
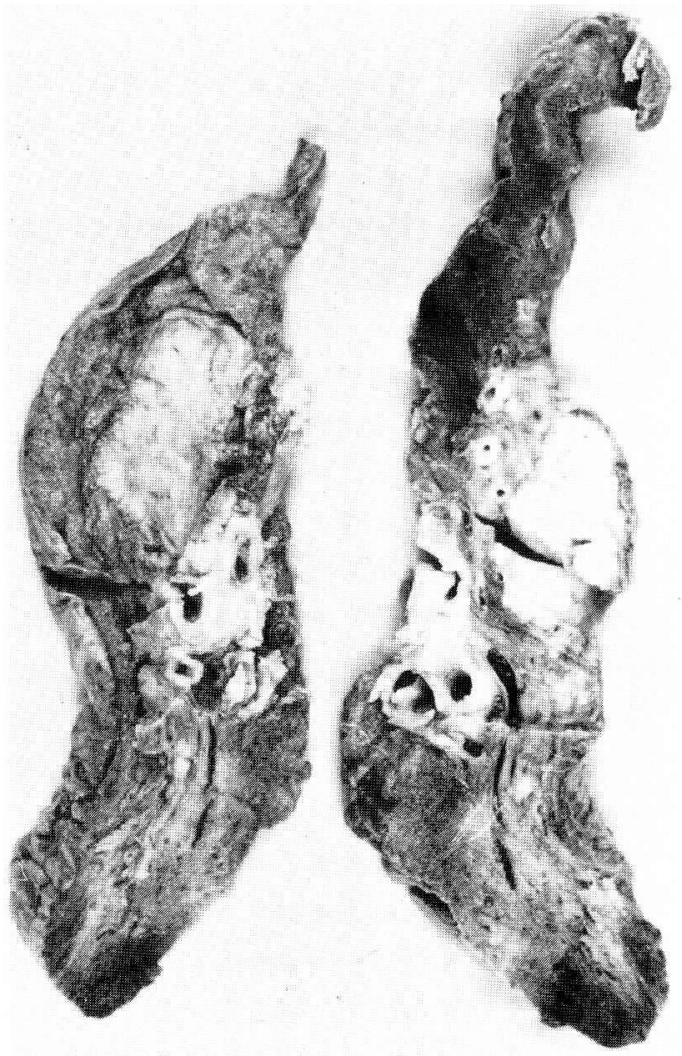

Fig.3 手術時, 腺房腺癌, 気管支腺の増生を思わ せる部分H.E. 染色.

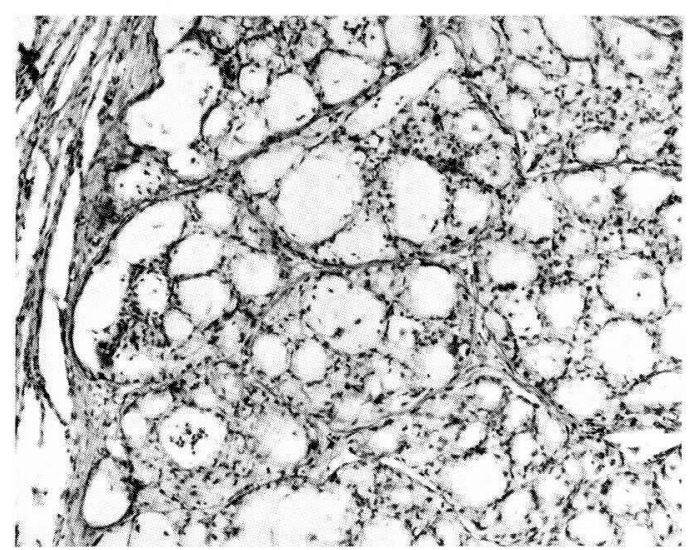

Fig.4 転移部 囊胞状腺癌で一部乳頭状を呈する。 間質結合織の増生 H. E. 染色

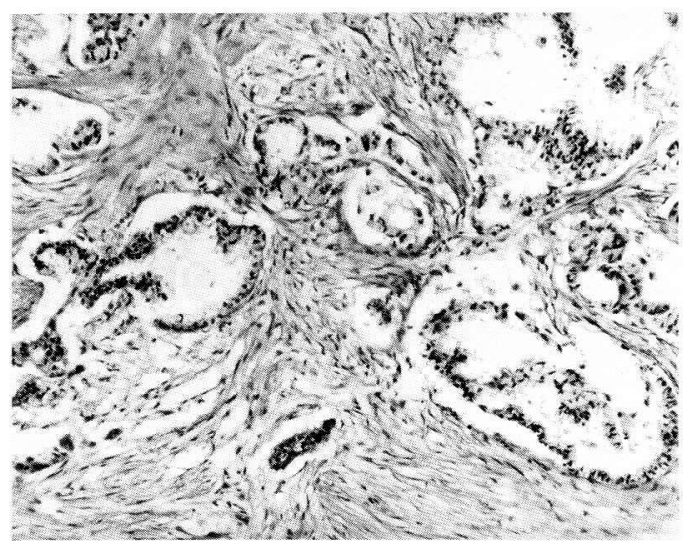

した，一部乳頭状増殖を呈する嗀胞状腺癌の部 分が見られた。所属りンパ節にはこの後者の部 分の転移像が見られた。

\section{経 過}

術後の経過は良好で，約 10 年間は臨床的に何 ら変化なかったが術後11年目の昭和 47 年10月に 感冒様症状で来院し, 胸部レ線にて両側肺野に 小川形陰影圭散見，右上肺野にも带状の異常㓌 影が出現してきた。(Fig.5)他臓器も精查したが 癌を疑之る所見なく，以前の腫瘍の再発と考之 られた。自覚的に軽度の咳嗽及び右前胸部痛が あり，時に血痰在認めた。そして昭和 48 年 4 月 頃より流動食の嬹下障害及び嗄声が出現してき 
Fig.5 再発時, 両肺野に小円形院影, 右上肺野に 異常㓌影が出現してきた。

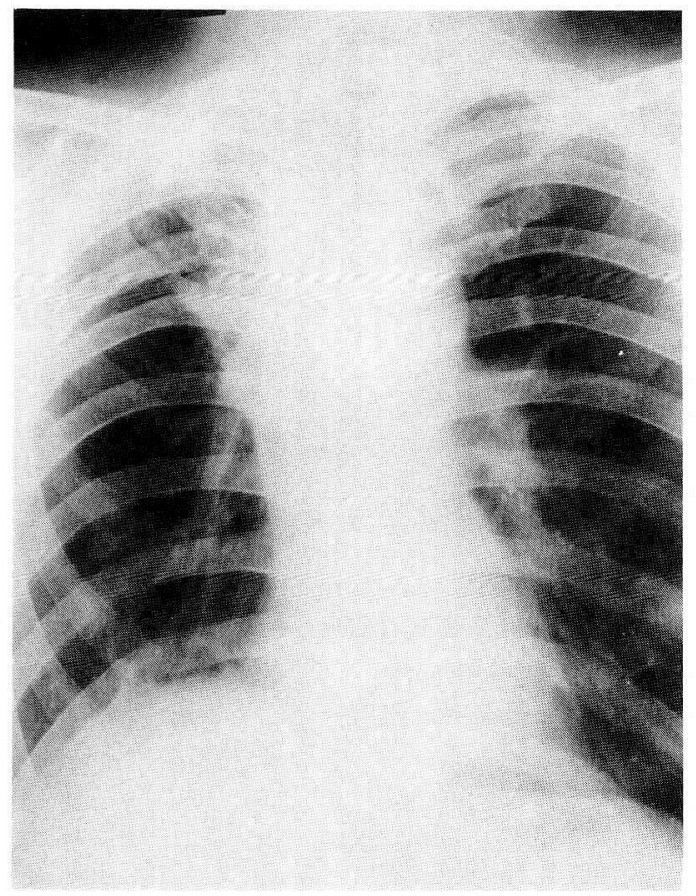

Fig.6 覀化時, 右上肺野の無気肺像, 右胸水出現, 左肺野の㓌影の増大.

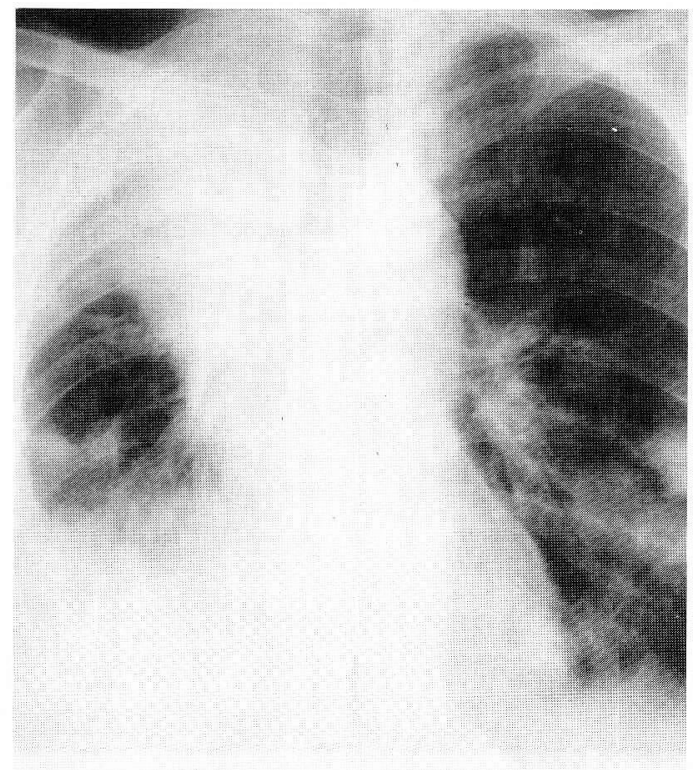

た。その後 1 年半余りはそ扎らの症状寻特に増 強することなく小康状態で経過した。しかし胸 部レ線上ではごく徐々にではあるが進展し，散 在子る小门形陰影も増大, 数毛增加し, 右主気 管支の圧排狭寯像及び右上肺野の無気肺像が見 られ，更に50年 2 月には右胸水の貯留を認めた。 (Fig.6) 胸水は黄褐色で混羁し, 癌細胞老認女 たが約 10 力月間著明な増加なく経過した。しか し昭和50年 12 月初旬より右胸水著明となり，呼 吸困難増強し，嚥下障害も強くなり，衰弱し同 月30日死亡した。全経過 14 年 7 力月，手術後 10 年数力月間臨床的に再発を認めず，再発後約 3 年 3 力月目に死亡した。

\section{治 療}

昭和37年 1 月右肺上葉切除，その前後に $\mathrm{MM}$ C，マーフィリン，コバルト照射を施行。再発 後は一時エンドキサン或いはエスキノンを静注 したが骨䯣抑制強く，内服では食欲不振の為い ずれもごく少量で中止した。胸水に対してはエ ンドキサンプレドニンを胸腔内に注入した。

\section{臨床検査成績(昭和50年末)}

\%肺活量は34\%と著減していた。貧血は軽度, 低アルブミン血症あり，血清アルホス中等度上 萛, CRP陽性, ツ反は疑陽性, ECGは洞頻脈の みで他は正常であった。

\section{部検所見}

開腹すると腹水はなく，右胸腔に血性混濁胸 水 $200 \mathrm{Cc}$ あり, 左胸腔に血性混罚䏫水 $1,100 \mathrm{CC}$ あ る。心のうは平滑で, 中に黄色やや混濁した心 のう液90CC圭認女る。心臓は重さ180gで特变な し、右肺は縮少し，全体が粘液を多量に伴う実 質性の塊となり胸壁，横隔膜と強くゆ着してい る。(Fig.7)肺門リンパ節転移あり。左肺は両葉 に, 死白色で直径約 $3 \mathrm{~cm}$ 結節が数個散在し, 結節の割面は白色で粘液に富む。肺門リンパ節 転移あり。肝，胆のう，脾，腎に異常起認めず。 食道は第二狭窄部で外部より圧迫されている。 噴門部リンパ節は $2 \times 1 \mathrm{~cm}$ と腫大. 膵体部周井 リンパ節 $2 \times 1.5 \mathrm{~cm}$ に腫大し, 左副腎周囲リン 
Fig. 7 右肺剖検時，粘液を多量に含んだ実質塊と なり，全体が縮少している。

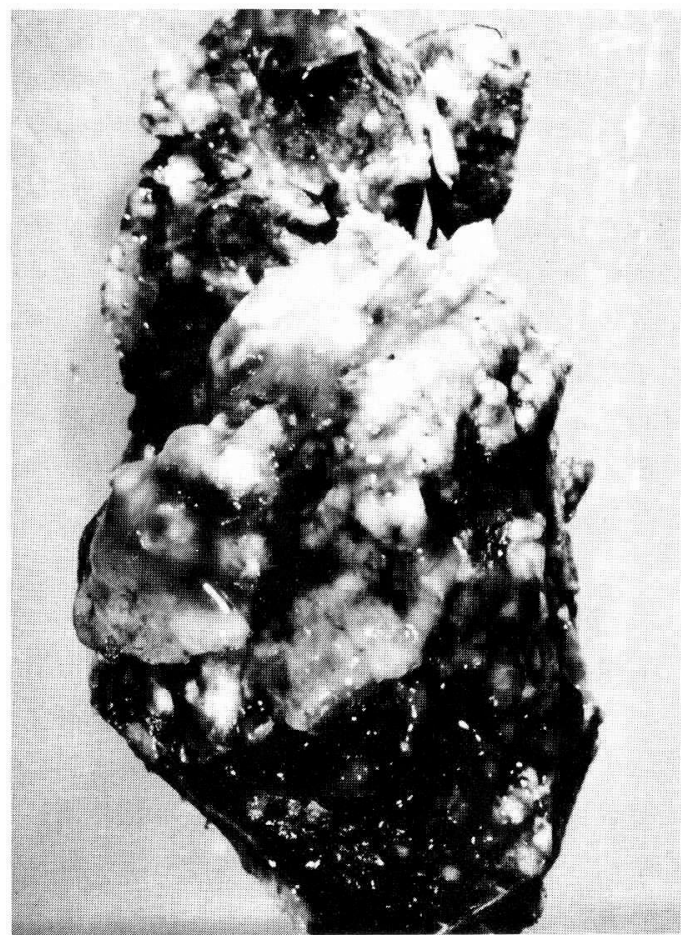

パ節は $2.5 \times 1.5 \mathrm{~cm}$ と腫大. 頸部, 気管周囲リン パ節も腫大している。胸骨は約 $6 \mathrm{~cm}$ に亘り灰白 色の転移女り， $\mathrm{L}_{4}, \mathrm{Th}_{4}, \mathrm{Th} \mathrm{h}_{6}$ の椎骨は白色化 している。また，右前頭葉に $2 \times 1 \mathrm{~cm}$, 左後頭 葉に0. $5 \mathrm{~cm}$ 径の腫瘤を認める。

\section{病理組織学的所見}

腫瘍組織はFig.8の上うに粘液分泌の強い円柱 状細胞が導管状あるいは囊胞状に管腔を形成し， 腔内に粘液を无満している。また，間質結合織 の増生が見られる。一方，他の部分ではFig.9の ような乳頭状，囊胞状増殖を呈する腺癌の像が 見られる。Fig.10は唾液腺腫瘍に似た腺房腺癌 の部分であるが，この像も腫陽転移部に多く見 られ，腺房腺癌と考えられる。いずれの部分で も肺胞壁の弾力線維はかなり保なれており(Elastica 染色), 管腔の部分に扔いてはPASの粘液 染色で強陽性であった。また，部分的に砂嵧体 の出現も見られた。
Fig. 8 囊胞状腺癌，腔内には粘液が充満している. H. E. 染色.

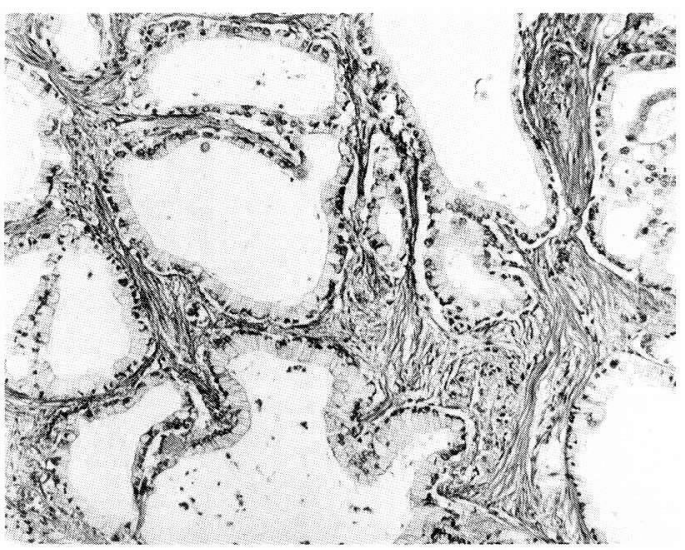

Fig.9 乳頭状, 囊胞状腺癌, H. E. 染色.

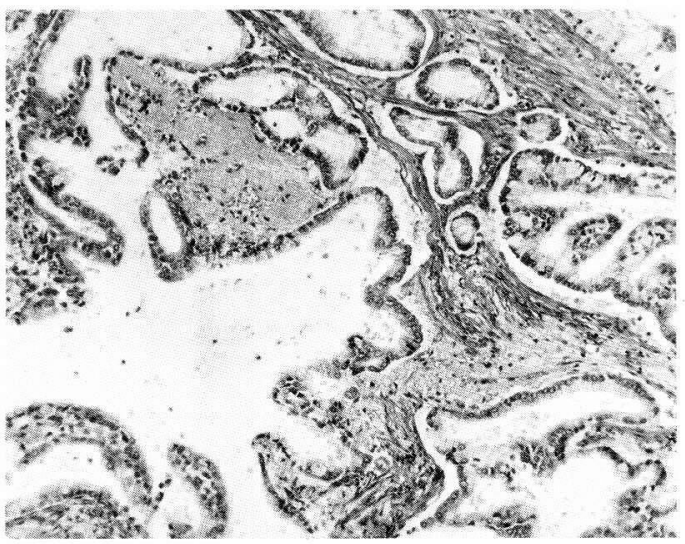

Fig. 10 唾液腺腫痬類似の腺房腺癌. H.E. 染色.

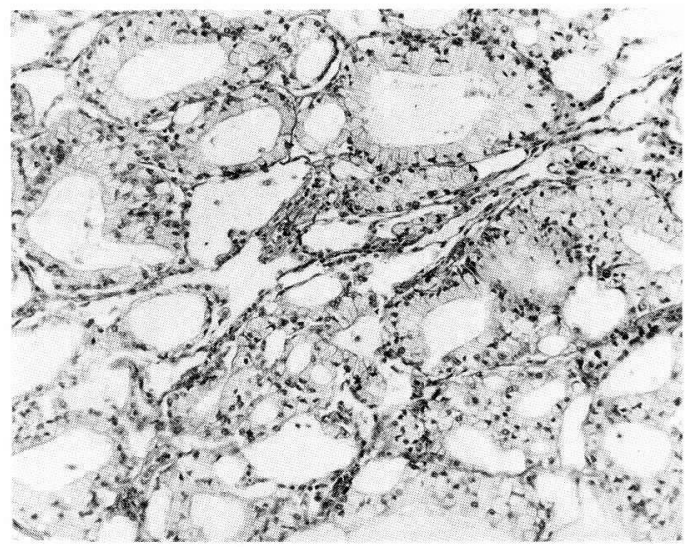




\section{病理解剖学的診断}

主診断は肺癌（右上葉原発の腺癌）で，転移 は右肺中下葉, 左肺, 横隔膜, 右胸膜, 胸骨, 椎骨，大脳，リンパ節（両肺門，気管周囲，両 側頸部，左副腎周囲，莝体，噴門部）に見られ た。副診断としては 1 , 右肺上葉切除後（昭和 36 年) 2 , 右癌性胸膜炎 3 , 左胸水 $(1,100 \mathrm{cc})$ 4 , 心筋褐色萎縮 5 , 大動脈硬化軽度, である.

\section{考 察}

気管支腺は “気管支唾液腺” の別名の如く唾 液腺と類似の腺組織であり, その腫瘍組織像は 良性悪性ともに気管支上皮由来の腫㾤よりも， むしろ唾液腺等の腺由来の腫瘍に類似を求めら れる。過去，気管支腺腫瘍として気管支腺腫が とり上げられ，その中に1) carcinoid 2)adenoid cystic carcinoma 3)mucoepidermoid carcinoma 4)mixed tumorなどが含まれていたがcarcinoid は最近oat cell carcinomaと共通の発生母地を有 すると考えられるようになってきており ${ }^{1}$ 最近の WHOの肺腫瘍の分類ではcarcinoidは気管支腺腫 瘍からはずされて独立している。また, carcinoid の発生は唾液腺などでは未だ経験されていない。 adenoid cystic carcinoma, mucoepidermoid carcinomaはともに唾液腺原発の同名の腫瘍と同 じでこの両者とも現在は気管支腺の腺房ある いは導管の上皮細胞に由来すると考えられてお り，その性質上低悪性度の腺澏であると理解さ れている。これらの他に唾液腺腫瘍類似の気管 支腺腫瘍の存在が考えられるが，その腫瘍に唾 液腺腫瘍の特徵的な所見がない限りはそれを気 管支腺由来と決定することは困難であり, 通常 の腺腫あるいは腺癌として扱われているものと 思われる.Weiss \& Ingram ${ }^{2)}$ は気管支腺原発腫 瘍のうちsalivary gland type neoplasmsとして
組織発生的に考えられるものを記載しており， Ramsey \& Reimann ${ }^{3)}$ が粘液分泌の著明な新し い型の腺腫を記載して以来, 少数ではあるが報 告が見られ，，5，6)，7)また，悪性化した気管支腺腫 としての報告 ${ }^{8), 9)}$ がこの腫瘍に当るのではないか と考えられる. 最近, 腺癌の中で電顕的検索に より明らかに気管支腺由来と考之られるものも 認められるようになった ${ }^{10)}$ が，その報告例は極 めて少ない。このような症例は一般の腺癌とは その組織像においても臨床像においても著しく 異なる例がある。この気管支腺原発の腫瘍の特 徵 ${ }^{10)}$ としては1）唾液腺腫瘍型である。2）粘液産 生が著明である，3) 悪性の場合でも一般にslow growingであるが予後は不良である,ことが上げ られる.Kirklinら ${ }^{11)}$ はmucous producing adenocarcinomaの予後は通常の腺癌よりも比較的良い のではないかと述べている。また一般に気管支 腺原発の腺癌は通常の腺癌より中枢側の気管支 から高率に発生する傾向がある ${ }^{12)}$ と言われてい るが我々の症例も右上葉気管支壁から発生して いる. 我々の症例は全経過 14 年 7 力月にび, 全身転移で死亡したがその組織像はmucous producing cystic adenocarcinoma とacinar adenocarcinomaの混在したものでRamsey ${ }^{3)}$ の cystadenoma とも言える症例の悪性化した気管支腺原 発の腺癌と考えられる。

\section{まとめ}

我々は約15年の全経過で死亡した肺癌の一例 を経験したが, その組織学的特異性から気管支 腺原発の腺癌と考えられ, 今までと違った新し い型の腺癌であるのでここに報告した。今後, 気管支腺より発生する腫瘍を再整理すべきであ ると考える。 
交献

1) 服部正次：癌の臨床, $17: 504,1971$.

6) Fechner, R.E., et al.: Cancer. $29: 501,1972$.

2) Weiss, L. \& Ingram, M. : Cancer, 14:161,1961.

7) 伊藤元彦ら：日本胸部臨床，34:137, 1975.

3) Ramsey, J. H. \& Reimann, D. L : Am. J. Path:,

8) 麻田栄ら：胸部外科, $9 ： 179 ， 1956$. $29: 339,1953$.

9）藤沢武彦ら：肺癌，12：37, 1972.

4) Spencer, H. : Pathology of the lung, London.

10）下里幸雄ら：癌の臨床，19：170，1973. p. $887,1977$.

11) Kirklin, J. W. : Surg. Gynec. \& Obst., 100 : $429,1955$.

5）姜臣国ら：第16回日本肺癌学会総会， 15:269, 1975.

12）高木佳木：肺癌，15:1，1975.

\title{
An autopsy case of bronchial grand adenocarcinoma survived for fifteen years
}

\author{
Keiichi Inada, et al.
}

\author{
Osaka Teishin Hospital
}

A 48 year-old man with lung cancer who died of general metastasis recurring 15 years after the right upper lobectomy was reported. Histopathologically it was a mucous producing cystic adenocarcinoma with acinar adenocarcinoma. It was suggested that this tumor was originated from broncial gland because of the resemblance to salivary gland tumor. 